\title{
DIFFICULTIES IN THE DIAGNOSIS OF HTLV-2 INFECTION IN HIVIAIDS PATIENTS FROM BRAZIL: COMPARATIVE PERFORMANCES OF SEROLOGIC AND MOLECULAR ASSAYS, AND DETECTION OF HTLV-2b SUBTYPE
}

\author{
Helena Kaminami MORIMOTO(1), Arilson Akira MORIMOTO(2), Edna Maria Vissoci REICHE(1), Luiz Toshio UEDA(3), Tiemi MATSUO(4),
} Fernando Vissoci REICHE(5) \& Adele CATERINO-DE-ARAUJO(6)

\begin{abstract}
SUMMARY
The current diagnosis of human T-lymphotropic virus type-2 (HTLV-2) infection is based on the search of specific antibodies; nevertheless, several studies conducted in Brazil pointed deficiencies of the commercially available kits in detecting HTLV-2, mostly in HIV/AIDS patients. This study searched for the presence of HTLV-1 and -2 in 758 HIV/AIDS patients from Londrina, Paraná, Brazil. Serum samples were screened for HTLV-1/2 antibodies using two EIA kits (Vironostika and Murex), and confirmed by WB (HTLV Blot 2.4, Genelabs). The results obtained by EIA disclosed 49 (6.5\%) reactive sera: 43 positive by both EIA kits, and six with discordant results. WB confirmed HTLV-1 infection in seven samples (0.9\%) and HTLV-2 in 21 sera (2.8\%). Negative and indeterminate results were detected in four $(0.5 \%)$ and $16(2.1 \%)$ sera, respectively. Blood from 47 out of 49 HTLV seroreactive patients were collected and analyzed for the presence of env, LTR and tax genomic segments of HTLVs by PCR. PCR confirmed six cases of HTLV-1 and 37 cases of HTLV-2 infection (14 out of 16 that were found to be WB indeterminate). Restriction analysis of the env PCR products of HTLV-2 disclosed 36 isolates of HTLV-2a/c subtype, and one of HTLV-2b subtype. These results emphasize the need of improving serologic tests for detecting truly HTLV-2 infected patients from Brazil, and confirm the presence of HTLV-2b subtype in the South of this country.
\end{abstract}

KEYWORDS: Human T-lymphotropic virus type 2 (HTLV-2); HIV/HTLV-2 coinfection; Diagnosis; Serology; PCR; HTLV-2 subtype.

\section{INTRODUCTION}

Human T-lymphotropic virus type 2 (HTLV-2) is a human retrovirus which is endemic in Amerindians from the Amazon region of Brazil, as well is epidemic among HIV/AIDS patients living in urban areas of this country ${ }^{28}$.

A recent molecular subtype of HTLV-2, named HTLV-2c, was recognized among endemic and epidemic populations from Brazil $^{13,15,16,18}$. The HTLV-2c is phylogenetically related to HTLV-2a, but possess an extended Tax protein, similar to HTLV-2 $b^{8,15,17}$. This diversity could account for the designation of HTLV-2c, which by some authors was previously considered as a molecular variant of HTLV$2 \mathrm{a}^{1,12,19,30,32}$.

In spite of the proximity of Brazil to other Latin America countries where HTLV-2b is endemic ${ }^{28}$, only recently this subtype was reported among urban population in Porto Alegre, South of Brazil ${ }^{27}$.
The routes of HTLV-2 transmission/acquisition differ from endemic and epidemic populations: breastfeeding and sexual contact has been reported as the major routes of transmission in endemic populations, while parenteral transmission by intravenous drug use (IDU) or sexual contact with IDU, are responsible for epidemic transmission of HTLV$2^{29}$.

Unfortunately, for Brazilian population, commercially available serologic kits lack in confirming HTLV-2 infection, especially in HIV/ AIDS coinfected patients ${ }^{6,9}$. Indeed, although the controversial role of HTLV-2 in the pathogenesis of several diseases, an association of neurological syndromes, pneumonia, bronchitis and arthritis, have been documented in HTLV-2-infected patients, as well as cutaneous lymphoma in few cases of HIV/HTLV-2 co-infected patients ${ }^{3-4,21,28}$. Paradoxically, antiretroviral therapy increases HTLV-2 proviral load, and may alter the course of HIV disease ${ }^{22,25}$. Thus, it is important to know the real status of HTLV-2 in HIV/AIDS patients in order to properly attend these individuals.

Support: CAPES, Instituto Adolfo Lutz

(1) Departamento de Patologia, Análises Clínicas e Toxicológicas, Centro de Ciências da Saúde, Universidade Estadual de Londrina, Paraná, Brasil.

(2) Divisão de Doenças Infecciosas, Departamento de Medicina Clínica, Centro de Ciências da Saúde, Universidade Estadual de Londrina, Paraná, Brasil.

(3) Centro Integrado de Doenças Infecciosas de Londrina, Londrina, Paraná, Brasil.

(4) Centro de Ciências Exatas e Bioestatística, Universidade Estadual de Londrina, Paraná, Brasil.

(5) Escola de Medicina, Centro de Ciências da Saúde, Universidade Estadual de Londrina, Paraná, Brasil.

(6) Seção de Imunologia, Instituto Adolfo Lutz, São Paulo, SP, Brasil.

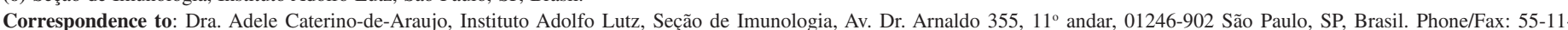
30682898. E-mail: caterino@ial.sp.gov.br 


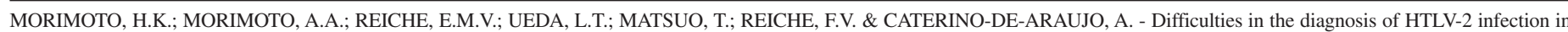
HIV/AIDS patients from Brazil: comparative performances of serologic and molecular assays, and detection of HTLV-2b subtype. Rev. Inst. Med. trop. S. Paulo, 49(4):225-230, 2007.

The aim of the present study was to detect the real prevalence of HTLV-2 infection in HIV/AIDS patients from the South of Brazil using serologic and molecular assays, and by restriction analysis of one segment of the env gene of HTLV-2, confirm HTLV-2b subtype in this geographic area.

\section{MATERIAL AND METHODS}

Ethical aspects: The study was approved by the Ethics Committees of Universidade Estadual de Londrina and of Universidade de São Paulo. Patients were enrolled either at admission to the health care units or during regular medical visits and were included after signing an informed consent form.

Study population: A cross-sectional study was conducted as an epidemiological investigation with descriptive and analytical components. Serial blood samples were obtained by time, place and conveniences. The population consisted of HIV-1-infected patients seen at different Regional Health Units of the AIDS Reference Centers (located in the cities of Londrina, Cornélio Procópio, Jacarezinho and Ivaiporã, in Paraná State, South Brazil).

Serologic screening tests for HTLV-1/2: Blood samples were collected from September 2001 to December 2002 and were tested for anti-HTLV-1/2 antibodies using two EIA kits with different antigens: one consisting of purified viral lysates of HTLV-1 and HTLV-2, associated with recombinant antigen p21E of HTLV-1 (Vironostika ${ }^{\mathrm{TM}}$ HTLV-I/II, BioMeriéux, Bostel, The Netherlands), and the other consisting of a synthetic peptide from the envelope protein of HTLV-1 and HTLV-2 associated with a recombinant transmembrane protein of HTLV-2 (Murex ${ }^{\mathrm{TM}}$ HTLV-I+II, Abbott, Dartford Kent England, UK). Reactive and discordant EIA samples were submitted to a confirmatory WB (HTLV BLOT 2.4 ${ }^{\mathrm{TM}}$, Abbott Murex, Singapore System, Abbott, Delkenhein, Germany). All assays were conducted and analyzed according to manufacturer instructions.

Molecular biology approaches to confirm HTLV-1 and -2 infections: Patients who presented reactive or indetermined results on WB assay were recalled for a new blood sampling. Peripheral mononuclear blood cells (PBMC) were obtained by density gradient centrifugation (Histopaque ${ }^{\mathrm{TM}}$ - 1077, Sigma, St. Louis, USA) and stored dry at $-20{ }^{\circ} \mathrm{C}$ for DNA extraction and polymerase chain reaction (PCR). Several genomic segments of HTLV-1 and HTLV-2 were amplified to confirm HTLV-1 and HTLV-2 infection and to discard false-negative or indeterminate results obtained by WB. Primers of the LTR, env and tax regions of the genome were used as previously described, and summarized in Table $1^{7}$. In addition, to confirm the HTLV-2b subtype, restriction fragment length polymorphism (RFLP) analyses were performed using the PCR env products and the restriction enzyme XhoI, of which the restriction site is present in HTLV-2a and 2c env sequences ${ }^{7-8}$, and absent in HTLV- $2 b^{5}$.

Table 1

Set of primers used to amplify segments of the env, LTR and tax regions of the genomes of HTLV-1 and HTLV-2, nucleotides (nt) position, and size of the amplified product in base pairs $(\mathrm{bp})$

\begin{tabular}{|c|c|c|c|c|}
\hline Region & Primer & Sequence $(5$ & Localization (nt) & Product $(\mathrm{bp})$ \\
\hline \multicolumn{5}{|c|}{ HTLV-1 } \\
\hline \multirow{4}{*}{ env } & D498 & d ATG GGT AAG TTT CTG GCC & $5202-5219^{a}$ & 1467 \\
\hline & D500 & d TTA CAG GGA TGA CTG AGG & $6668-6651$ & \\
\hline & TS1 & d TTA TTC TTC CAG TTC TGC C & $5229-5247$ & 1421 \\
\hline & TS2 & d GTT TAT AAG AGA GTA ATG G & $6649-6632$ & \\
\hline \multirow[t]{3}{*}{$L T R$} & LTR1 & d AAT ATC CCC CGG GGG CTT AGA & $22-42^{b}$ & 500 \\
\hline & LTR3 & d CAA GGG AGC GCC GGA CAA AG & $521-502$ & \\
\hline & LTR2 & d CCA CGC TTT TAT AGA CTC CTG & $337-317$ & 316 \\
\hline \multirow[t]{2}{*}{ tax/rex } & HTLV3 & d GGA TAC CCC GTC TAC GTG TTT & $7339-7359^{a}$ & 212 \\
\hline & HTLV4 & d GTG GTT CTC TGG GTG GGG AA & $7550-7531$ & \\
\hline \multicolumn{5}{|c|}{ (6) } \\
\hline \multirow[t]{4}{*}{ env } & envA & d ATG GGT AAT GTT TTC TTC & $5180-5197^{\mathrm{c}}$ & 1463 \\
\hline & envB & d TAT TAT AGC ATG GTT TCT & $6642-6625$ & \\
\hline & LUI7 & d CCG TCT CCA GTC CAT CCT GGA & $5547-5567$ & 763 \\
\hline & LUI8 & d CCT CGT CTA TTT TGG GCT GCA & $6309-6289$ & \\
\hline \multirow[t]{4}{*}{$L T R$} & VS1 & d CAG GGC GAG TCA TCG ACC CAA AAG & $35-58^{c}$ & 712 \\
\hline & VS2 & d GAA GAC AAT GCT CCT AGG GCG GGC & $746-724$ & \\
\hline & VS3 & d ACC GTC TCA CAC AAA CAA TCC C & $64-85$ & 666 \\
\hline & VS4 & d GCG GGC CTG CCT ATA GCG ATG & 729-709 & \\
\hline \multirow[t]{3}{*}{$\operatorname{tax}$} & $\operatorname{tax} 3$ & d CGG CCT TTT GCT GTC CTT & $7077-7094^{\mathrm{d}}$ & 1254 \\
\hline & $\operatorname{tax} 4$ & d GTC AGG GCC TTG GTT TCA & $8330-8313$ & \\
\hline & $\operatorname{tax} 5$ & d GCA CCA GCT CAC CT & 7364-7377 & 967 \\
\hline
\end{tabular}

${ }^{a}$ relative to ATK isolate of HTLV-1, accession number J02029; ${ }^{\text {b }}$ relative to HS35 isolate of HTLV-1, accession number D13784; ${ }^{\mathrm{c}}$ relative to MoT isolate of HTLV-2, accession number M10060; ${ }^{\text {d }}$ relative to NRA isolate of HTLV-2, accession number L20734. 


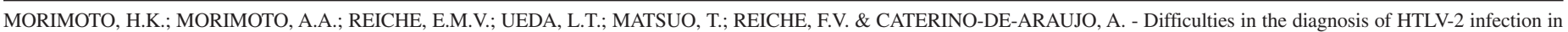
HIV/AIDS patients from Brazil: comparative performances of serologic and molecular assays, and detection of HTLV-2b subtype. Rev. Inst. Med. trop. S. Paulo, 49(4):225-230, 2007.

Table 2

Results obtained by screening and confirmatory tests for HTLV-1 and HTLV-2 infections, and HTLV-2 subtyping among 49 HIV/AIDS patients from Londrina and region

\begin{tabular}{|c|c|c|c|c|c|c|c|}
\hline \multirow[t]{2}{*}{ Pt n. } & \multicolumn{2}{|c|}{$\begin{array}{l}\text { Viral lysate EIA } \\
\text { Vironostika }^{\mathrm{TM}}\end{array}$} & \multicolumn{2}{|c|}{$\begin{array}{c}\text { Recombinant EIA } \\
\text { Murex }^{\mathrm{TM}}\end{array}$} & \multirow[t]{2}{*}{$\begin{array}{l}\text { WB pattern } \\
\text { HTLV } 2.4^{\mathrm{TM}}\end{array}$} & \multirow[t]{2}{*}{ PCR } & \multirow[t]{2}{*}{$\begin{array}{c}\text { RFLP } \\
\text { env } H T L V-2\end{array}$} \\
\hline & Result & $\mathrm{OD} / \mathrm{CO}$ & Result & $\mathrm{OD} / \mathrm{CO}$ & & & \\
\hline 1 & + & 1.3 & - & 0.3 & - & - & \\
\hline 2 & + & 1.9 & + & $>9.0$ & Ind. (GD21,rgp46-II) & + & $2 \mathrm{a} / \mathrm{c}$ \\
\hline 3 & + & 1.4 & + & $>9.0$ & Ind. (GD21,rgp46-II) & + & $2 \mathrm{a} / \mathrm{c}$ \\
\hline 4 & + & 1.4 & + & $>9.0$ & Ind. (GD21) & + & $2 \mathrm{a} / \mathrm{c}$ \\
\hline 5 & - & 0.8 & + & 7.7 & Ind. (GD21) & + & $2 \mathrm{a} / \mathrm{c}$ \\
\hline 6 & - & 0.6 & + & $>9.0$ & Ind. (GD21,rgp46-II) & + & $2 \mathrm{a} / \mathrm{c}$ \\
\hline 7 & + & 1.4 & + & $>9.0$ & HTLV-2 & + & $2 \mathrm{a} / \mathrm{c}$ \\
\hline 8 & + & 2.6 & + & $>9.0$ & Ind. (GD21,p24) & + & $2 \mathrm{a} / \mathrm{c}$ \\
\hline 9 & + & 1.9 & + & $>9.0$ & HTLV-2 & + & $2 \mathrm{a} / \mathrm{c}$ \\
\hline 10 & + & 1.2 & + & $>9.0$ & HTLV-2 & + & $2 \mathrm{a} / \mathrm{c}$ \\
\hline 11 & + & 1.7 & + & $>9.0$ & HTLV-2 & + & $2 \mathrm{a} / \mathrm{c}$ \\
\hline 12 & + & 4.3 & + & $>9.0$ & HTLV-2 & + & $2 \mathrm{a} / \mathrm{c}$ \\
\hline 13 & + & 3.1 & + & $>9.0$ & HTLV-2 & + & $2 \mathrm{a} / \mathrm{c}$ \\
\hline 14 & + & 3.4 & + & $>9.0$ & HTLV-1 & + & ND \\
\hline 15 & + & 3.9 & + & $>9.0$ & HTLV-1 & + & ND \\
\hline 16 & + & 1.5 & + & $>9.0$ & Ind. (GD21) & + & $2 \mathrm{a} / \mathrm{c}$ \\
\hline 17 & + & 1.4 & + & $>9.0$ & - & - & ND \\
\hline 18 & - & 0.8 & + & 8.4 & Ind. (GD21,rgp46-II) & + & $2 \mathrm{a} / \mathrm{c}$ \\
\hline 19 & + & 1.0 & + & 8.9 & Ind. (GD21,rgp46-II) & + & $2 \mathrm{a} / \mathrm{c}$ \\
\hline 20 & - & 0.9 & + & 2.2 & - & - & ND \\
\hline 21 & + & 1.7 & + & $>9.0$ & Ind. (GD21,p24) & + & $2 \mathrm{a} / \mathrm{c}$ \\
\hline 22 & + & 1.4 & + & $>9.0$ & Ind. (GD21,p24) & + & $2 \mathrm{a} / \mathrm{c}$ \\
\hline 23 & + & 1.8 & + & $>9.0$ & HTLV-2 & + & $2 \mathrm{a} / \mathrm{c}$ \\
\hline 24 & + & 1.8 & + & $>9.0$ & HTLV-2 & + & $2 \mathrm{a} / \mathrm{c}$ \\
\hline 25 & + & 1.7 & + & $>9.0$ & HTLV-2 & + & $2 \mathrm{a} / \mathrm{c}$ \\
\hline 26 & + & 2.5 & + & $>9.0$ & HTLV-2 & + & $2 \mathrm{a} / \mathrm{c}$ \\
\hline 27 & + & 2.4 & + & $>9.0$ & HTLV-2 & + & $2 \mathrm{a} / \mathrm{c}$ \\
\hline 28 & + & 3.4 & + & $>9.0$ & HTLV-2 & + & $2 \mathrm{a} / \mathrm{c}$ \\
\hline 29 & + & 2.1 & + & $>9.0$ & HTLV-2 & + & $2 \mathrm{a} / \mathrm{c}$ \\
\hline 30 & + & 2.2 & + & $>9.0$ & HTLV-1 & + & ND \\
\hline 31 & + & 3.6 & + & 3.1 & - & ND & ND \\
\hline 32 & - & 0.9 & + & 7.0 & Ind. (GD21,p24) & + & $2 \mathrm{a} / \mathrm{c}$ \\
\hline 33 & + & 1.1 & + & 9.0 & Ind. (GD21,p24) & ND & ND \\
\hline 34 & + & 2.4 & + & $>9.0$ & Ind. (GD21,p24) & - & ND \\
\hline 35 & + & 1.2 & + & 9.0 & Ind. (rgp46-II) & + & $2 \mathrm{a} / \mathrm{c}$ \\
\hline 36 & + & 1.2 & + & $>9.0$ & HTLV-2 & + & $2 \mathrm{a} / \mathrm{c}$ \\
\hline 37 & + & 4.1 & + & $>9.0$ & HTLV-2 & + & $2 \mathrm{a} / \mathrm{c}$ \\
\hline 38 & + & 1.6 & + & $>9.0$ & HTLV-2 & + & $2 \mathrm{a} / \mathrm{c}$ \\
\hline 39 & + & 1.8 & + & $>9.0$ & HTLV-2 & + & $2 \mathrm{a} / \mathrm{c}$ \\
\hline 40 & + & 3.0 & + & $>9.0$ & HTLV-2 & + & $2 \mathrm{a} / \mathrm{c}$ \\
\hline 41 & + & 3.7 & + & $>9.0$ & HTLV-2 & + & $2 \mathrm{a} / \mathrm{c}$ \\
\hline 42 & + & 3.8 & + & $>9.0$ & HTLV-2 & + & $2 \mathrm{a} / \mathrm{c}$ \\
\hline 43 & + & 3.6 & + & $>9.0$ & HTLV-1 & + & ND \\
\hline 44 & + & 3.7 & + & $>9.0$ & HTLV-1 & + & $2 \mathrm{a} / \mathrm{c}$ \\
\hline 45 & + & 3.1 & + & $>9.0$ & HTLV-1 & + & ND \\
\hline 46 & + & 1.1 & + & $>9.0$ & HTLV-1 & + & ND \\
\hline 47 & + & 1.3 & + & $>9.0$ & Ind. (GD21,p24) & + & $2 b$ \\
\hline 48 & + & 3.1 & + & $>9.0$ & HTLV-2 & + & $2 \mathrm{a} / \mathrm{c}$ \\
\hline 49 & + & 1.3 & + & $>9.0$ & HTLV & + & $2 \mathrm{a} / \mathrm{c}$ \\
\hline
\end{tabular}

HTLV-1 - Human T-lymphotropic virus type 1; HTLV-2 - Human T-lymphotropic virus type 2; HIV/aids - Human immunodeficiency virus/acquired immunodeficiency syndrome; HTLV-1/2 - Human T-lymphotropic virus type 1 and 2; HTLV - Human T-lymphotropic virus not typing; Pt n. - Patient number; EIA - Enzyme-linked immunosorbent assay; WB - Western Blotting; OD/CO - optic density/cut-off; Ind - Indeterminate; (-) - negative; (+) - positive; PCR - Polymerase chain reaction; RFLP - Restriction fragment length polymorphism; ND - Not done. 


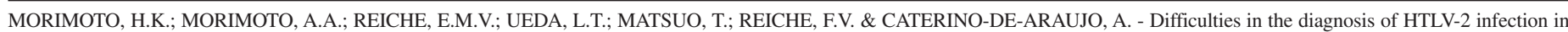
HIV/AIDS patients from Brazil: comparative performances of serologic and molecular assays, and detection of HTLV-2b subtype. Rev. Inst. Med. trop. S. Paulo, 49(4):225-230, 2007.

\section{RESULTS}

From September 2001 to December 2002, 784 HIV-1-infected patients were attended at the AIDS Reference Centers in Londrina and region where their blood samples were collected. Twenty-six (3.3\%) of 784 patients did not allow blood collection and were excluded from the study. Among 758 serum samples analyzed for the presence of HTLV-1/2 antibodies by the EIA viral lysate kit and EIA recombinant kit, $709(93.5 \%)$ resulted non-reactive and $49(6.5 \%)$ were reactive in at least one of the kits.

Forty-three sera $(87.8 \%)$ presented concordant results with EIA tests; out of these, two (4.7\%) were WB negative, seven $(16.3 \%)$ confirmed infection by HTLV-1, 21 (48.8\%) by HTLV-2, one $(2.3 \%)$ by HTLV. It was not possible to confirm infection by HTLV in 12 cases $(27.9 \%)$, evidencing an indeterminate WB pattern (Table 2).

Six serum samples $(12.2 \%)$ resulted discordant in the screening EIA tests, and when analyzed by WB, two (33.3\%) were considered negative and four (66.7\%) HTLV indeterminate (Table 2).

For the 49 reactive or discordant samples in the serologic screening, it was possible to perform PCR in 47 cases (95.9\%), of which four $(8.5 \%)$ resulted negative and $43(91.5 \%)$ confirmed the presence of DNA/HTLV in the PBMC for the three different regions of the genome. Of these, $37(86 \%)$ were HTLV-2 positive and six (14\%) were HTLV1 positive. One sample (pt. 44) showed discordant results: HTLV-1 seroreactivity and HTLV-2 truly infection by PCR analysis. This patient was then referred to a new blood collection and the results confirmed previous information (Table 2).
Using WB as the "gold standard" to define HTLV-1 and -2 infections, the results demonstrated that both EIA kits were highly sensitive in detecting HTLV-1 and HTLV-2 antibodies (Table 3). On the other hand, in using PCR as the "gold standard", the ELISA recombinant test was more sensitive than the viral lysate EIA for detecting HTLV-2-specific antibodies (100.0\% vs $89 \%$ sensitivity, respectively) (Table 4 ). When a $20.0 \%$ reduced cut-off value was used for the viral lysate assay, the sensitivity of HTLV-2 antibody detection was increased; however, one case that was classified as HTLV-2 positive by PCR remained negative with the reduced cut-off (pt. 6, Table 2).

The 37 PCR positive samples for HTLV-2 had their env PCR products tested by the RFLP technique in order to rapidly search for HTLV-2b subtype. One out of 37 amplicons did not present the restriction site for enzyme $X h o \mathrm{I}$ and was subtyped as HTLV-2b, while $36(97.3 \%)$ presented this site and were subtyped as HTLV-2a/c.

\section{DISCUSSION}

The municipality of Londrina ranks second in the number of AIDS cases in the Paraná State, Brazil, and almost the totality of HIV/AIDS patients attended at the AIDS Reference Centers in Londrina and region during the years of 2001-2002 had their blood collected and analyzed previously for the seroprevalence and risk factors for HTLV-1 and -2 , as well as hepatitis B virus (HBV), hepatitis $\mathrm{C}$ virus (HCV) and syphilis. The results obtained disclosed an overall seroprevalence of $6.4 \%$ for HTLV-1/2; $0.8 \%$ for HTLV-1 and $4.9 \%$ for HTLV-2, and a strong association with $\mathrm{IDU}^{24}$. On the other hand, Brazil is a country which possess HTLV-2 endemic and epidemic populations, but the majority of epidemiological and molecular studies referred data on the North

Table 3

Comparison of the HTLV-1/2 serological results obtained in a population of 758 HIV-1-infected individuals using the Western Blot test as the gold standard

\begin{tabular}{|c|c|c|c|c|c|}
\hline Western Blot & $\mathrm{n}$ & $\begin{array}{c}\text { Viral lysate } \\
\text { EIA-Vironostika }^{\mathrm{TM}}\end{array}$ & $\begin{array}{l}\text { Sensitivity } \\
(\%)\end{array}$ & $\begin{array}{l}\text { Recombinant } \\
\text { EIA - Murex }\end{array}$ & $\begin{array}{c}\text { Sensitivity } \\
(\%)\end{array}$ \\
\hline HTLV-1 Positive & 7 & 7 & 100 & 7 & 100 \\
\hline HTLV-2 Positive & 21 & 21 & 100 & 21 & 100 \\
\hline HTLV Positive & 1 & 1 & 100 & 1 & 100 \\
\hline Indeterminate & 16 & 12 & 75 & 16 & 100 \\
\hline Negative & 4 & 3 & 75 & 3 & 75 \\
\hline
\end{tabular}

HIV-1 - Human immunodeficiency virus type 1; n - population; EIA - Enzyme immunoassay; HTLV-1 - Human T-lymphotropic virus type 1; HTLV-2 - Human T-lymphotropic virus type 2; HTLV - Human T-lymphotropic virus not typing.

Table 4

Comparison of the HTLV-1/2 serological results obtained in a population of 758 HIV-1 infected individuals using PCR assay as the gold standard

\begin{tabular}{|c|c|c|c|c|c|}
\hline PCR & $\mathrm{n}$ & $\begin{array}{c}\text { Viral lysate } \\
\text { EIA-Vironostika }^{\mathrm{TM}}\end{array}$ & $\begin{array}{c}\text { Sensitivity } \\
(\%)\end{array}$ & $\begin{array}{l}\text { Recombinant } \\
\text { EIA - Murex }\end{array}$ & $\begin{array}{c}\text { Sensitivity } \\
(\%)\end{array}$ \\
\hline HTLV-1 Positive & 6 & 6 & 100 & 6 & 100 \\
\hline HTLV-2 Positive & 37 & 33 & 89 & 37 & 100 \\
\hline Negative & 4 & 3 & 75 & 3 & 75 \\
\hline
\end{tabular}

HIV-1 - Human immunodeficiency virus type 1; n - population; EIA - Enzyme immunoassay; HTLV-1 - Human T-lymphotropic virus type 1; HTLV-2 - Human T- lymphotropic virus type. 


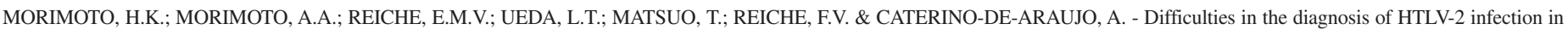
HIV/AIDS patients from Brazil: comparative performances of serologic and molecular assays, and detection of HTLV-2b subtype. Rev. Inst. Med. trop. S. Paulo, 49(4):225-230, 2007.

and Southeast regions of Brazil ${ }^{28}$. Only very recently, a study conducted in Porto Alegre, South of Brazil, disclosed the presence of both, HTLV2a and HTLV-2b among urban individuals from this geographic area. Thus, in order to add some information concerning HTLV-1 and -2 infections in the South of Brazil, we conducted the present study.

The same cohort of HIV/AIDS patients from Londrina and region early evaluated for HTLV-1/2 seroprevalence ${ }^{24}$, were now confirmed HTLV-1 and - 2 infected by molecular approaches, and careful analysis of serologic screening tests was performed in order to establish the ideal testing algorithm useful in Brazil.

The serological analysis disclosed both EIAs as $100 \%$ sensitive in detecting HTLV-1 infection, the same sensitivity previously described for HTLV-1 infection in Japan ${ }^{14}$. In contrast, for HTLV-2 truly infection, the viral lysate EIA kit detected only $89 \%$ of cases, while the recombinant EIA, $100 \%$ of cases. These results are in accordance with the results obtained by others ${ }^{2,26}$.

The strategy of using two, instead of one, EIA screening test for HTLV-2 serology, increased the sensitivity in detecting HTLV-2 from $89.9 \%$ to $97.5 \%$. Indeed, the EIAs which have recombinant proteins and/or synthetic peptides of HTLV-1 and of HTLV-2 and that use the "sandwich" principle, are highly sensitive and specific in detecting HTLV antibodies when compared with indirect assays that use only viral lysates 2,33 . Here, the recombinant test ("sandwich") showed the best performance in detecting HTLV-2-infected patients, including patients whose sera resulted indeterminate on WB.

Of note, the indeterminate WB profile observed in the present study differs from the HTLV-1 gag indeterminate profile (HGIP) described in Africa, associated with $P$. falciparum infection ${ }^{23}$. Here, the majority of sera presented reactivity to GD21 and/or gp46-II, p24, and could reflect HTLV-2 seroconversion. Delayed HTLV-1 seroconversion in sero-indeterminate blood donors from endemic regions were early detected $^{11}$.

Previous studies showed that WB has a sensitivity ranging from $70 \%$ to $84 \%$ in detecting HTLV-2 infection ${ }^{26,31}$, and the PCR's sensitivity of $85.1 \%{ }^{20}$. Thus, both tests lack in detecting all HTLV-2-infected cases, requiring an association of the $\mathrm{WB}$ and PCR assays ${ }^{26}$.

The Centers for Disease Control (CDC) using a questionnaire sent to several laboratories in the United States showed that only $18.5 \%$ of the laboratories performed the WB test, and $8.8 \%$ used other methods including PCR, antigen detection, radioimmunoprecipitation assay (RIPA), and viral culture ${ }^{10}$. At Brazilian blood centers, the serologic screening of HTLV-1/2 infection with two EIAs of different principles seems to be enough to discard donation bags. On the other hand, whether the purpose is to diagnose HTLV-2 infection in high-risk population, the recombinant EIA and PCR assays seems to be the best choice.

An interesting event detected in the present study was the discordant results obtained by WB and PCR in one patient; he was considered HTLV-1-infected by the WB test, and HTLV-2-infected by the PCR of the env, LTR and tax regions of the virus genome. A second blood collection and analyses of this patient supported the results previously obtained. Thus, we could hyphotesize that antibodies against gp46 of the HTLV-2 strain that infect this patient cross-react with the rgp46-I present on the WB strip. Similar discordant results were described in other infected patients from Brazil ${ }^{6,9}$.

The sole HTLV-2b case detected in the present study contrast with the large number of cases detected in Porto Alegre ${ }^{27}$. Nevertheless, we have to consider the risk factors and HIV status of the populations analyzed, which could influence on the results obtained. Interestingly, the HTLV-2b-infected patient from Londrina was of a Paraguayan origin.

In conclusion, the data presented in this study suggest the use of recombinant EIA as screening, and PCR as confirmatory tests in HTLV2 diagnosis of high-risk population of Brazil, and confirm the presence of HTLV-2b in the South of this country.

\section{RESUMO}

\section{Dificuldades no diagnóstico de infecção por HTLV-2 em pacientes com HIV/AIDS do Brasil: análise comparativa de ensaios sorológicos e moleculares e detecção de subtipo HTLV-2b}

O diagnóstico de infecção por HTLV-2 se baseia na pesquisa de anticorpos específicos, entretanto, vários estudos conduzidos no Brasil têm apontado falhas nos kits sorológicos disponíveis no mercado em detectar HTLV-2, principalmente nos pacientes com HIV/aids. Este trabalho avaliou a presença de infecção por HTLV-1 e -2 em 758 pacientes HIV/aids de Londrina, Paraná, Brasil. Amostras de soro foram analisadas quanto à presença de anticorpos anti-HTLV-1/2 por dois kits de EIA (Vironostika e Murex) e confirmados por WB (HTLV Blot 2.4, Genelabs). Os resultados obtidos pelos testes sorológicos mostraram $49(6,5 \%)$ soros reagentes: 43 positivos para ambos os kits e seis com resultados discordantes. O WB confirmou infecção por HTLV-1 em sete soros (0,9\%) e HTLV-2 em 21 soros (2,8\%). Resultados negativos e indeterminados foram detectados, respectivamente, em quatro $(0,5 \%)$ e $16(2,1 \%)$ soros. Amostras de sangue de 47 dos 49 pacientes com sorologia reagente foram avaliadas quanto à presença de segmentos do genoma dos HTLVs (env, LTR e tax), usando a técnica de PCR. As PCRs confirmaram seis casos de infecção por HTLV-1 e 37 casos por HTLV-2 (14 dos 16 cuja sorologia resultou WB indeterminada). A subtipagem de HTLV-2 por análise de restrição enzimática de produtos da PCR env mostrou 36 isolados de subtipo HTLV-2a/c e um HTLV-2b. Esses resultados reforçam a necessidade de melhorar o diagnóstico de infecção por HTLV-2 no Brasil e confirmam a presença do subtipo HTLV-2b na região sul do país.

\section{REFERENCES}

1. ALCANTARA, L.C.J.; SHINDO, N.; VAN DOREN, S. et al. - Brazilian HTLV type 2a strains from intravenous drug users (IDUs) appear to have originated from two sources: Brazilian Amerindians and European/North American IDUs. AIDS Res. hum. Retrovir., 19: 519-523, 2003.

2. ANDERSSON, S.; THORSTENSSON, R.; RAMIREZ, K.G. et al. - Comparative evaluation of 14 immunoassays for detection of antibodies to the human Tlymphotropic virus types I and II using panels of sera from Sweden and West Africa. Transfusion, 39: 845-851, 1999.

3. ARAUJO, A. \& HALL, W.W. - Human T-lymphotropic virus type II and neurological disease. Ann. Neurol., 56: 10-19, 2004. 


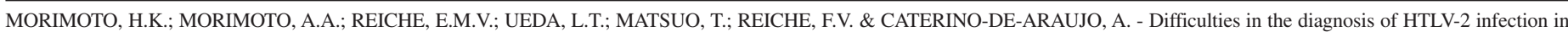
HIV/AIDS patients from Brazil: comparative performances of serologic and molecular assays, and detection of HTLV-2b subtype. Rev. Inst. Med. trop. S. Paulo, 49(4):225-230, 2007.

4. ARAUJO, A.; SHEEHY, N.; TAKAHASHI, H. et al. - Concomitant infections with human immunodeficiency virus type 1 and human T-lymphotropic virus types 1 and 2 . In: BROGDEN, K.A. \& GUTHMILLER, J.M., ed. Polymicrobial diseases. Washington, ASM, 2002. p. 75-97.

5. CALABRÒ, M.L.; LUPARELlO, M.; GROTTOLA, A. et al. - Detection of human Tlymphotropic virus type II/b in human immunodeficiency virus type 1-coinfected persons in southeastern Italy. J. infect. Dis., 168: 1273-1277, 1993.

6. CASSEB, J.; CATERINO-DE-ARAUJO, A.; HONG, M.A. et al. - Prevalence of HTLVI and HTLV-II infections among HIV-1-infected asymptomatic individuals in São Paulo, Brazil. Rev. Inst. Med. trop. S. Paulo, 39: 213-215, 1997.

7. CATERINO-DE-ARAUJO, A.; FAVERO, A.; SANTOS-FORTUNA, E. et al. - HTLV-I/ HTLV-II coinfection in an AIDS patient from São Paulo, Brazil. AIDS Res. hum. Retrovir., 16: 715-719, 2000

8. CATERINO-DE-ARAUJO, A.; FAVERO, A.; SANTOS-FORTUNA, E. et al. - Molecular characterization of HTLV strains from HIV-1-infected intravenous drug users from São Paulo, Brazil. In: INTERNATIONAL CONFERENCE ON HUMAN RETROVIROLOGY: HTLV, 8., Rio de Janeiro, 1997. p. ME08.

9. CATERINO-DE-ARAUJO, A.; SANTOS-FORTUNA, E.; MELEIRO, M.C.Z. et al. Sensitivity of two enzyme-linked immunosorbent assay tests in relation of Western Blot in detecting human T-cell lymphotropic virus types I and II infection among HIV-1 infected patients from São Paulo, Brazil. Diagn. Microbiol. infect. Dis., 30: $173-182,1998$

10. CDC. Centers for Disease Control and Prevention - Results of the 1999 retroviral testing survey questionnary sent to laboratories participating in the model performance evaluation program, 1999, July 15, 2001. Available at: http://www.phppo.cdc.gov/ mpip/pdf/rq9903.

11. CÉSAIRE, R.; BERA, O.; MAIER, H. et al. - Seroindeterminate patterns and seroconversions to human T-lymphotropic virus type I positivity in blood donors from Martinique, French West Indies. Transfusion, 39: 1145-1149, 1999.

12. COVAS, D.T. \& KASHIMA, S. - Complete nucleotide sequences of the genomes of two Brazilian specimens of human T lymphotropic virus type 2 (HTLV-2). AIDS Res. hum. Retrovir., 19: 689-697, 2003.

13. EIRAKU, N.; NOVOA, P.; DA COSTA FERREIRA, M. et al. - Identification and characterization of a new and distinct molecular subtype of human T-cell lymphotropic virus type 2. J. Virol., 70: 1481-1492, 1996.

14. FUJIYAMA, C.; FUJIYOSHI, T.; MATSUMOTO, D.; TAMASHIRO, H. \& SONODA, S. - Evaluation of commercial HTLV-1 test kits by a standard HTLV-1 serum panel. Bull. Wld Hlth Org., 73: 515-521, 1995.

15. ISHAK, R.; HARRINGTON Jr., W.J.; AZEVEDO, V.N. et al. - Identification of human T cell lymphotropic virus type IIa infection in the Kayapo, an indigenous population of Brazil. AIDS Res. hum. Retrovir., 11: 813-821, 1995.

16. ISHAK, R.; VALLINOTO, A.C.R.; AZEVEDO, V.N. \& ISHAK, M.Q. - Epidemiological aspects of retrovirus (HTLV) infection among Indian populations in the Amazon Region of Brazil. Cadern. Saúde públ. (Rio de J.), 19: 109-114, 2003.

17. LAL, R.B.; PARDI, D.; SWITZER, W.; SEGURADO, A. \& BLACK, F. - Immune reactivity of HTLV-IIa-infected Kayapo Indians with HTLV-IIb extended tax epitope. J. acquir. immune Defic. Syndr. hum. Retrovir., 14: 476-477, 1997.

18. LAURENTINO, R.V.; LOPES, I.G.L.; AZEVEDO, V.N. et al. - Molecular characterization of human T-cell lymphotropic virus coinfecting human immunodeficiency virus 1 infected patients in the Amazon region of Brazil. Mem. Inst. Oswaldo Cruz, 100: 371-376, 2005
19. LEWIS, M.J.; NOVOA, P.; ISHAK, R. et al. - Isolation, cloning, and complete nucleotide sequence of a phenotypically distinct Brazilian isolate of human T-lymphotropic virus type II (HTLV-II). Virology, 271: 142-154, 2000.

20. LIU, H.; SHAH, M.; STRAMER, S.L. et al. - Sensitivity and specificity of human Tlymphotropic virus (HTLV) types I and II polymerase chain reaction and several serologic assays in screening a population with a high prevalence of HTLV-II Transfusion, 39: 1185-1193, 1999.

21. MACEDO, O.; RIBEIRO-LIMA, T.V.; LINHARES, A.O. et al. - Human T-cel lymphotropic virus types I and II infections in a cohort of patients with neurological disorders in Belém, Pará, Brazil. Rev. Inst. Med. trop. S. Paulo, 46: 13-17, 2004.

22. MACHUCA, A. \& SORIANO, V. - In vivo fluctuation of HTLV-I and HTLV-II proviral load in patients receiving antiretroviral drugs. J. acquir. immune Defic. Syndr., 24 189-193, 2000.

23. MAHIEUX, R.; HORAL, P.; MAUCLÈRE, P. et al. - Human T-cell lymphotropic virus type 1 gag indeterminate Western blot patterns in Central Africa: relationship to Plasmosium falciparum infection. J. clin. Microbiol., 38: 4049-4057, 2000.

24. MORIMOTO, H.K.; CATERINO-DE-ARAUJO, A.; MORIMOTO, A.A. et al. Seroprevalence and risk factors for human $\mathrm{T}$ cell lymphotropic virus type 1 and 2 infection in human immunodeficiency virus-infected patients attending AIDS Referral Center Health Units in Londrina and other communities in Paraná, Brazil. AIDS Res. hum. Retrovir., 21: 256-262, 2005.

25. MURPHY, E.L.; GRANT, R.M.; KROPP, J. et al. - Increased human T-lymphotropic virus type II proviral load following highly active retroviral therapy in HIV-coinfected patients. J. acquir. immune Defic. Syndr., 33: 655-656, 2003.

26. POIESZ, B.J.; DUBE, S.; CHOI, D. et al. - Comparative performances of an HTLV-I/II EIA and other serologic and PCR assays on sample from persons at risk for HTLVII infection. Transfusion, 40: 924-930, 2000.

27. RENNER, J.D.P.; LAURINO, J.P.; MENNA-BARRETO, M. \& SCHMITT, V.M. Molecular evidence of HTLV-II subtype $b$ among urban population living in South Brazil. AIDS Res. hum. Retrovir., 22: 301-306, 2006.

28. ROUCOUX, D.F. \& MURPHY, E.L. - The epidemiology and disease outcomes of human T-lymphotropic virus type II. AIDS Rev., 6: 144-154, 2004.

29. SALEMI, M.; LEWIS, M.; EGAN, J.F. et al. - Different population dynamics of human T cell lymphotropic virus type II in intravenous drug users compared with endemically infected tribes. Proc. nat. Acad. Sci. (Wash.), 96: 13253-13258, 1999.

30. SHINDO, N.; ALCANTARA, L.C.J.; VAN DOOREN, S. et al. - Human retroviruses (HIV and HTLV) in Brazilian Indians: seroepidemiological study and molecular epidemiology of HTLV type 2 isolates. Aids Res. hum. Retrovir., 18: 71-77, 2002

31. THORSTENSSON, R.; ALBERT, J. \& ANDERSSON, S. - Strategies for diagnosis of HTLV-I and II. Transfusion, 42: 780-791, 2002.

32. VANDAMME, A.M.; SALEMI, M.; VAN BRUSSEL, M. et al. - African origin of human T-lymphotropic virus type 2 (HTLV-2) supported by a potential new HTLV-2d subtype in Congolese Bambuti Efe Pygmies. J. Virol., 72: 4327-4340, 1998.

33. VRIELINK, H.; REESINK, H.W.; HABIBUW, M. et al. - Comparison of four HTLV-I and HTLV-I + II ELISAs. Vox Sang. (Basel), 76: 187-191, 1999.

Received: 25 July 2006

Accepted: 28 November 2006 